\title{
Multiple kidney of the Baikal seal in early postnatal ontogenesis: structure and topograpy
}

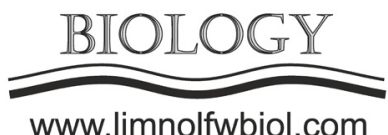

\author{
Pomoynitskaya T.E. \\ Irkutsk State Agricultural Academy, Irkutsk, Russia
}

\begin{abstract}
The article presents the results of studies on the anatomical structure of the kidneys of the Baikal seal in early postnatal ontogenesis. A number of morphological features were identified by the anatomical methods (including anatomical preparation, infusion with polyurethane foam through the ureter). The Baikal seal kidneys are multiple, of a bunch shape. They are located in the lumbar zone of the mesogastric at the level of the second, third and fourth lumbar vertebrae. Their weight, width, height, and thickness were measured. Height and width of the kidneys and their structure were determined. By injecting the excretory ducts with polyurethane foam, the structure and size of the renal calyx, length and width of the renal stalk (excretory duct) in early postnatal ontogenesis were determined. The age was determined by annual dentine rings of the canine base (the transverse canine cut) and claw rollers (by the Chapsky's method).
\end{abstract}

Keywords: anatomical features of the kidney of the Baikal seal, seal kidney, multiple kidney, topography of the seal kidneys, Baikal seal

\section{Introduction}

Baikal Lake is unique by its biological diversity and the number of endemic species, including the Baikal seal (Phoca sibirica Gmelin, 1798). In total, there are 2595 species and subspecies, of which 1500 are endemic organisms (Petrov, 2009).

The biological characteristics of the seal were studied by V. D. Pastukhov, and E. A. Petrov (Bogdanov et al., 1982; Petrov, 2009). A.A. Mayboroda and B.A. Chernyak described the kidney's structure; however, its anatomical features in early postnatal ontogenesis have not been identified yet. We have studied the structure and topography of the kidneys in the postnatal ontogenesis. This research aims to study the structure and topography of the kidneys in the early postnatal period (Mayboroda and Chernyak,1982; Gladkaya, 2014).

\section{Material and methods}

The material for the study was the kidneys of three seals aged one month. The age was determined by annual dentine rings and the transverse cut of the canine base (Klevezal and Kleinenberg, 1967; Anoshko et al., 2000).

The following anatomical methods were used: anatomical preparation; manufacture of corrosive preparations (infusion of kidneys with foam through the ureter and dissolution of the organ tissues with alkali $(\mathrm{NaOH})$ ), statistical processing of the numerical data in Statistics, Microsoft Excel, a manual on biometrics and Biometrics software, and photographing.

\section{Results and Discussion}

The kidneys of the Baikal seal are of a multiple type, have a bunch shape. This structure is characteristic of many aquatic mammals (dolphins and whales, seals, sea lions and walruses) and polar bears (Bester, 1975; Vardy and Bryden, 1981; Gladkaya, 2014).

In the Baikal seal, the kidneys are located symmetrically relative to the spinal column in the lumbar zone of the mesogastrium at the level of the second, third and fourth lumbar vertebrae.

The kidney is $52.75 \pm 0.45 \mathrm{~mm}$ long, 23.5 $\pm 0.39 \mathrm{~mm}$ wide and $17.7 \pm 0.28 \mathrm{~mm}$ thick, beanshaped. Its mass is $29.75 \pm 0.37 \mathrm{~g}$. There are cranial and caudal ends, dorsal and ventral surfaces, and lateral and medial edges. Kidney gates, which are an entrance for the renal artery and an exit for the ureter, are located on the medial edge. The kidney is covered with a fibrous capsule. The fat capsule was not found in the kidneys of the Baikal seal.

The kidney consists of many miniature kidneys whose number varies from 58 to 61 . Each kidney is of a pyramidal shape, $5.9 \pm 0.65 \mathrm{~mm}$ high, $5.7 \pm 0.44 \mathrm{~mm}$ wide. Each kidney has its own ductal system, which 
includes collecting ducts that form the renal papilla, a renal calyx, and a renal stalk (an excretory duct) 2-4 $\mathrm{mm}$ long and $0.5 \pm 0.04 \mathrm{~mm}$ wide. The merging stems form larger ducts. The kidney has cortical and cerebral zones. The cortical, or urinary zone, is $2.4 \pm 0.66 \mathrm{~mm}$ wide. It is of burgundy color. It forms the surface layer of the kidney; the cerebral or urinary zone is $3.2 \pm$ $0.33 \mathrm{~mm}$ wide. It is of pale pink color. It is represented by the renal papilla entering the renal calyx (Gladkaya, 2014; Ryadinskaya and Gladkaya, 2015).

\section{Conclusion}

1. The kidneys are of a multiple type and a bunch shape.

2. The kidneys are located at the level of the second, third, and fourth lumbar vertebrae.

3. The kidney has cortical and cerebral zones.

4. Each kidney has a ductal system consisting of collecting ducts, a renal calyx, and a renal stalk.

\section{References}

Anoshko P.N., Goldberg E.L., Pastukhov M.V. et al. 2000. A retrospective analysis of the elemental composition of the teeth of the Baikal seal as a method for identifying biotic and abiotic changes in the environment. In: Third Vereshchagin Baikal Conference, p. 12. (in Russian)

Bester M.N. 1975. The functional morphology of the kidney of the Cape fur seal, Arctocephalus pusillus (Schreber). Madoqua 4: 69-92.

Bogdanov V.D., Pastukhov L.V., Ivanov M.K. 1982. Morfofiziologicheskiye i ekologicheskiye issledovaniya baykal'skoy nerpy [Morphophysiological and environmental studies of the Baikal seal]. Moscow: Nauka. (in Russian)

Gladkaya T.E. 2014. Anatomical features of the Baikal seal. In: The Student's Scientific and Practical Conference with International Participation Dedicated to the 80th Anniversary of the ISAA, pp. 27-31. (in Russian)

Klevezal G.A., Kleinenberg S.E. 1967. Opredeleniye vozrasta mlekopitayushchikh (po sloistym strukturam zubov i kosti) [Determination of the age of mammals (by the layered structures of teeth and bones)]. Moscow: Nauka. (in Russian)

Kutyrev I.A., Pronin N.M., Imikhelova L.S. et al. 2006. Baykal'skaya nerpa. Pasport i bibliografiya [The Baikal seal. Passport and bibliography]. Ulan-Ude: BSC SB RAS. (in Russian)

Mayboroda A.A., Chernyak B.A. 1982. Morfologicheskaya kharakteristika nekotorykh organov baykal'skoy nerpy [Morphological characteristics of organs of the Baikal seal]. In: Bogdanov V.D., Pastukhov L.V., Ivanov M.K. (Eds.), Morfofiziologicheskiye i ekologicheskiye issledovaniya baykal'skoy nerpy [Morphophysiological and environmental studies of the Baikal seal]. Novosibirsk: Nauka, pp. 12-19. (in Russian)

Petrov E.A. 2009. Baikal'skaya nerpa [Baikal seal]. Ulan-Ude: Baelig. (in Russian)

Ryadinskaya N.I., Gladkaya T.E. 2015. Microcirculatory bed of the cortical zone of the kidneys of the Baikal seal. In: The IVth International Scientific and Practical Conference "Climate, Ecology, Agriculture of Eurasia", pp. 256-263. (in Russian)

Vardy P.H., Bryden M.M. 1981. The kidney of Leptonychotes weddelli (Pinnipedia: Phocidae) with some observations on the kidneys of two other southern phocid seals. Journal of Morphology 167: 13-34. DOI: 10.1002/ jmor.1051670103 